\title{
Loss of steroid hormone receptors is common in malignant pleural and peritoneal effusions of breast cancer patients treated with endocrine therapy
}

\author{
Willemijne A.M.E. Schrijver ${ }^{1}$, Karianne Schuurman ${ }^{2}$, Annelot van Rossum ${ }^{2}$, Dutch \\ Distant Breast Cancer Metastases Consortium ${ }^{* *}$, Ton Peeters ${ }^{1}$, Natalie Ter Hoeve ${ }^{1}$, \\ Wilbert Zwart ${ }^{2, *}$, Paul J. van Diest ${ }^{1, *}$ and Cathy B. Moelans ${ }^{1, *}$ \\ ${ }^{1}$ Department of Pathology, University Medical Center Utrecht, The Netherlands \\ 2 Division of Molecular Pathology, The Netherlands Cancer Institute, The Netherlands \\ * These authors have contributed equally to this work \\ ** Members are listed in the acknowledgement \\ Correspondence to: Cathy B. Moelans, email: c.b.moelans@umcutrecht.nl
}

Keywords: breast cancer, distant metastases, receptor conversion, effusions

Received: October 26, $2016 \quad$ Accepted: February 12, $2017 \quad$ Published: February 20, 2017

Copyright: Schrijver et al. This is an open-access article distributed under the terms of the Creative Commons Attribution License 3.0 (CC BY 3.0), which permits unrestricted use, distribution, and reproduction in any medium, provided the original author and source are credited.

\section{ABSTRACT}

Discordance in estrogen receptor alpha (ERa), progesterone receptor (PR), androgen receptor (AR) and human epidermal growth factor receptor 2 (HER2) status between primary breast cancers and solid distant metastases ("conversion") has been reported previously. Even though metastatic spread to the peritoneal and pleural cavities occurs frequently and is associated with high mortality, the rate of receptor conversion and the prognostic implications thereof remain elusive.

We therefore determined receptor conversion in 91 effusion metastases ( 78 pleural, 13 peritoneal effusions) of 69 patients by immunohistochemistry (IHC) and in situ hybridization. Data were coupled to clinical variables and treatment history.

$E R a, P R$ and AR receptor status converted from positive in the primary tumor to negative in the effusion metastases or vice versa in $25-30 \%, 30-35 \%$ and $46-$ $51 \%$ of cases for the $1 \%$ and $10 \%$ thresholds for positivity, respectively. $19-25 \%$ of patients converted clinically relevant from "ERa+ or PR+" to ERa-/PR- and 3-4\% from ERa-/PR- to "ERa+ or PR+". For HER2, conversion was observed in $6 \%$ of cases. Importantly, receptor conversion for ERa $(p=0.058)$ and AR $(p<0.001)$ was more often seen in patients adjuvantly treated with endocrine therapy. Analogous to this observation, HER2-loss was more frequent in patients adjuvantly treated with trastuzumab $(p<0.001)$.

Alike solid distant metastases, receptor conversion for ERa, PR, AR and HER2 is a frequent phenomenon in peritoneal and pleural effusion metastases. Adjuvant endocrine and trastuzumab therapy imposes an evolutionary selection pressure on the tumor, leading to receptor loss in effusion metastases. Determination of receptor status in malignant effusion specimens will facilitate endocrine treatment decisionmaking at this lethal state of the disease, and is hence recommended whenever possible.

\section{INTRODUCTION}

Each year, around 550.000 women die from the consequences of breast cancer [1], largely due to metastatic relapse. In around $30 \%$ of patients with metastatic breast cancer, the pleural cavity is involved $[2,3]$ and less frequently the pericardial and peritoneal cavities $[4,5]$. The presence of metastatic breast carcinoma 
cells in effusions is associated with poor prognosis and a median survival of 5 months [2, 3, 6-8].

Immunohistochemistry (IHC) plays a valuable role in effusion cytology for the identification of metastatic malignancy. Inclusion of hormone receptor status assessment could direct treatment decision-making. This is underlined by the finding that tamoxifen treatment showed a therapeutic benefit in patients with ER $\alpha$-positive malignant pleural effusions [9-11].

In the clinical management of metastatic breast cancer, the choice of systemic treatment is traditionally based on the tissue characteristics of the primary tumor. Several previous studies have however shown that the expression of predictive tissue markers including ER $\alpha, P R$ and HER2 may differ between the primary breast tumor and solid distant metastases ("receptor conversion") in a significant proportion of patients [12-14]. Prolonged evolutionary pressure invoked by systemic endocrine therapies may effect hormone receptor expression, and with that, alter drug response. Consequently, alterations of hormone receptor expression in metastatic lesions in relation to the primary tumor may directly result in inappropriate endocrine treatment selection. Several guidelines therefore now recommend to biopsy distant metastases, and to reassess hormone and HER2 receptor status by IHC whenever possible $[15,16]$.

Androgen receptor (AR) is expressed in 60\% of breast cancers and is more frequently expressed in ER $\alpha$ positive than in ER $\alpha$-negative tumors. AR signaling pathways show a distinct pattern, depending on the breast cancer subtypes. In ER $\alpha$-positive breast cancer, AR is thought to antagonize the proliferative effect of ER $\alpha$ and in ER $\alpha$-negative tumors, AR signaling has a proliferative role [17]. In a comparison of $\mathrm{ER} \alpha$ - and AR-positive breast cancer and paired local recurrences or solid distant metastases, AR expression is often maintained even when ER $\alpha$-expression is lost $[18,19]$. This suggests that anti-androgens may be a useful therapeutic strategy for patients with anti-estrogen resistant metastatic disease. Therefore, clinical trials addressing AR-targeted therapies in metastatic breast cancer are currently performed (http:// www.cancer.gov/about-cancer/treatment/clinical-trials/, trial IDs NCI-2015-02043 and NCT02605486). However, the role of ER $\alpha$-inhibitor induced selective pressure on AR receptor status in distant metastases remaines to be elucidated.

To our knowledge, there have been no studies on the influence of adjuvant endocrine therapies on receptor conversion between primary breast tumors and their corresponding malignant effusions so far, while this is a frequent metastatic site $[20,21]$. Furthermore, also information about differences between receptor expression in solid and effusion metastases is lacking, due to small sample sizes of the reported studies [22, 23].

Here we report IHC staining of ER $\alpha, \mathrm{PR}, \mathrm{AR}$ and HER2 complemented with HER2 in situ hybridization in 69 patients with primary breast carcinomas and their matched malignant peritoneal and/or pleural effusions and solid distant metastases. We furthermore investigated the influence of adjuvant therapies on receptor conversion. Extensive knowledge of possible receptor conversion in malignant effusions could facilitate optimizing patient tailored therapy strategies for metastatic breast cancer patients.

\section{RESULTS}

\section{Decreased hormone receptor levels in malignant pleural and peritoneal effusions}

In total, 69 female breast cancer patients were included in this study with a median age at diagnosis of the primary tumor of 56 years (Table 1). The primary lesions were predominantly of the ductal type and $38 \%$ of patients who underwent sentinel node biopsy had positive lymph nodes. Ninety-one malignant effusions were investigated; 78 of pleural and 13 of peritoneal origin. For sixteen patients, two or more consecutive samples were available.

$\mathrm{ER} \alpha$ positivity was observed in the vast majority of primary tumors $(65 \%$ or $71 \%$ for the $10 \%$ or $1 \%$ thresholds for positivity, respectively). Solid metastases were more often ER $\alpha$ negative $(p=0.022$ for the $10 \%$ threshold and $p=0.079$ for the $1 \%$ threshold; ER $\alpha$ positivity of $38 \%$ for both thresholds), as was the case for effusion metastases ( $p=0.024$ and $p=0.097$; ER $\alpha$ positivity of $46 \%$ or $57 \%$ for the $10 \%$ or $1 \%$ thresholds for positivity, respectively). PR positivity was generally lower than ER $\alpha$ in the primary tumors $(p=0.004$ and $p=0.154$; PR positivity of $39 \%$ or $58 \%$, respectively). AR was expressed in $60 \%$ or $71 \%$ of primary tumors and $10 \%$ or $26 \%$ of effusion metastases (Figure $1 ; p<0.001$ for the $10 \%$ and $1 \%$ thresholds for positivity, respectively).

\section{Frequent hormone receptor discordance in paired breast cancer and effusion metastases}

$\mathrm{ER} \alpha, \mathrm{PR}$ and AR showed a significantly lower expression in effusion samples compared to the paired primary tumors $(p<0.001$ for all three receptors; $\mathrm{n}=$ $69)$. For the $10 \%$ theshold for positivity, $30 \%(21 / 69)$ of patients showed ER $\alpha$ conversion, with 26\% (18/69) from positive in the primary tumor to negative in the effusions and 4\% (3/69) from negative to positive. For PR, conversion rates were similar (total $30 \% ; 21 / 69$ ), with $25 \%(17 / 69)$ of samples converting from positive to negative and 5\% (4/69) from negative to positive. For AR, discordance was even higher with 50\% (35/69) of samples converting from positive to negative, and 1\% (1/69) conversion from negative to positive. When comparing solid metastases to paired effusion metastases, ER $\alpha$, PR 
Table 1: Clinical characteristics of the patients and pathological characteristics of primary breast carcinomas in this study.

\begin{tabular}{|c|c|c|c|}
\hline Feature & Grouping & N or value & $\%$ \\
\hline Age at primary diagnosis (in years) & $\begin{array}{l}\text { Median } \\
\text { Range }\end{array}$ & $\begin{array}{c}56 \\
32-85\end{array}$ & \\
\hline Tumor size (in $\mathrm{cm}$ ) & $\begin{array}{l}\text { Median } \\
\text { Range }\end{array}$ & $\begin{array}{c}2.4 \\
0.6-10.0\end{array}$ & \\
\hline Histologic type & $\begin{array}{c}\text { Invasive ductal } \\
\text { Invasive lobular } \\
\text { Invasive ductolobular } \\
\text { Not available } \\
\end{array}$ & $\begin{array}{c}52 \\
6 \\
5 \\
6 \\
\end{array}$ & $\begin{array}{c}75 \\
9 \\
7 \\
9 \\
\end{array}$ \\
\hline Histologic grade (Bloom \& Richardson) & $\begin{array}{c}\text { I } \\
\text { II } \\
\text { III } \\
\text { Not available }\end{array}$ & $\begin{array}{c}4 \\
27 \\
30 \\
8\end{array}$ & $\begin{array}{c}6 \\
39 \\
43 \\
12\end{array}$ \\
\hline Mitotic activity index (per $\left.2 \mathrm{~mm}^{2}\right)$ & $\begin{array}{l}\text { Median } \\
\text { Range }\end{array}$ & $\begin{array}{c}10 \\
0-60\end{array}$ & \\
\hline Lymph node status & $\begin{array}{c}\text { Negative } \\
\text { Positive } \\
\text { Not available }\end{array}$ & $\begin{array}{l}17 \\
26 \\
26\end{array}$ & $\begin{array}{l}24 \\
38 \\
38 \\
\end{array}$ \\
\hline Site of distant solid metastases $(\mathrm{n}=15)$ & $\begin{array}{c}\text { GI-tract/gynaecological } \\
\text { Skin } \\
\text { Lung } \\
\text { Bone } \\
\text { Liver } \\
\end{array}$ & $\begin{array}{l}6 \\
9 \\
2 \\
2 \\
2 \\
\end{array}$ & $\begin{array}{l}29 \\
44 \\
9 \\
9 \\
9\end{array}$ \\
\hline Site of metastases in body effusions $(n=69)$ & $\begin{array}{l}\text { Pleural effusion } \\
\text { Ascites }\end{array}$ & $\begin{array}{l}78 \\
13 \\
\end{array}$ & $\begin{array}{l}86 \\
14 \\
\end{array}$ \\
\hline $\begin{array}{l}\text { Time between diagnosis of primary and first effusion metastasis } \\
\text { (in months) }\end{array}$ & $\begin{array}{l}\text { Median } \\
\text { Range }\end{array}$ & $\begin{array}{c}45 \\
0-241\end{array}$ & \\
\hline $\begin{array}{l}\text { Survival time between diagnosis of first effusion metastasis and } \\
\text { end of follow-up (in days) }\end{array}$ & $\begin{array}{l}\text { Median } \\
\text { Range }\end{array}$ & $\begin{array}{c}120 \\
0-4477\end{array}$ & \\
\hline Adjuvant endocrine therapy & $\begin{array}{c}\text { Yes } \\
\text { No } \\
\text { Unknown }\end{array}$ & $\begin{array}{l}33 \\
18 \\
18\end{array}$ & $\begin{array}{l}48 \\
26 \\
26\end{array}$ \\
\hline Adjuvant chemotherapy & $\begin{array}{c}\text { Yes } \\
\text { No } \\
\text { Unknown } \\
\end{array}$ & $\begin{array}{l}31 \\
18 \\
20 \\
\end{array}$ & $\begin{array}{l}45 \\
26 \\
29 \\
\end{array}$ \\
\hline Adjuvant targeted therapy & $\begin{array}{c}\text { Yes } \\
\text { No } \\
\text { Unknown } \\
\end{array}$ & $\begin{array}{c}8 \\
40 \\
21 \\
\end{array}$ & $\begin{array}{l}12 \\
58 \\
30\end{array}$ \\
\hline
\end{tabular}

and AR protein expression diverged in $20 \%$ of cases $(3 / 15$; Table 2).

For the $1 \%$ threshold for positivity, less conversion was seen. $25 \%(17 / 69)$ of patients showed ER $\alpha$ conversion, with $21 \%(14 / 69)$ from positive in the primary tumor to negative in the effusions and $4 \%(3 / 69)$ from negative to positive. For PR, 35\% (24/69) converted in total, with $30 \%(21 / 69)$ of samples converting from positive to negative and $5 \%(3 / 69)$ from negative to positive. For AR, 43\% (30/69) of samples converted from positive to negative, and 3\% (2/69) from negative to positive. When comparing solid metastases to paired effusion metastases, ER $\alpha$ diverged in $20 \%(3 / 15)$, PR in $13 \%(2 / 15)$ and $\mathrm{AR}$ in $20 \%(3 / 15)$ of cases (Table 2$)$.
Clinically relevant conversion (from "ER $\alpha+$ or $\mathrm{PR}+$ " to $\mathrm{ER} \alpha-/ \mathrm{PR}-$, or from $\mathrm{ER} \alpha-/ \mathrm{PR}-$ to "ER $\alpha+$ or $\mathrm{PR}+$ ") was perceived in $28 \%(19 / 69)$ of patients for the $10 \%$ threshold and in $23 \%(16 / 69)$ of patients for the $1 \%$ threshold. $25 \%(17 / 69)$ and $19 \%$ (13/69) of patients, respectively, converted from "ER $\alpha+$ or PR+" to ER $\alpha$-/PRand 3\% (2/69) and 4\% (3/69) of patients from ER $\alpha$-/PR- to "ER $\alpha+$ or PR+".

HER2 discordance was seen in 6\% (4/69) of cases, were $3 \%(2 / 69)$ shifted from positive to negative and $3 \%$ $(2 / 69)$ from negative to positive (Table 3). Concordance between IHC and FISH for 0, 1+ (being non-amplified) and $3+$ cases (being amplified) was high $(88 \%, 23 / 26$, Table 4). 
Table 2: Immunohistochemical hormone receptor status (ERo, PR and AR) of primary tumors and solid and effusion metastases of patients analyzed in this study.

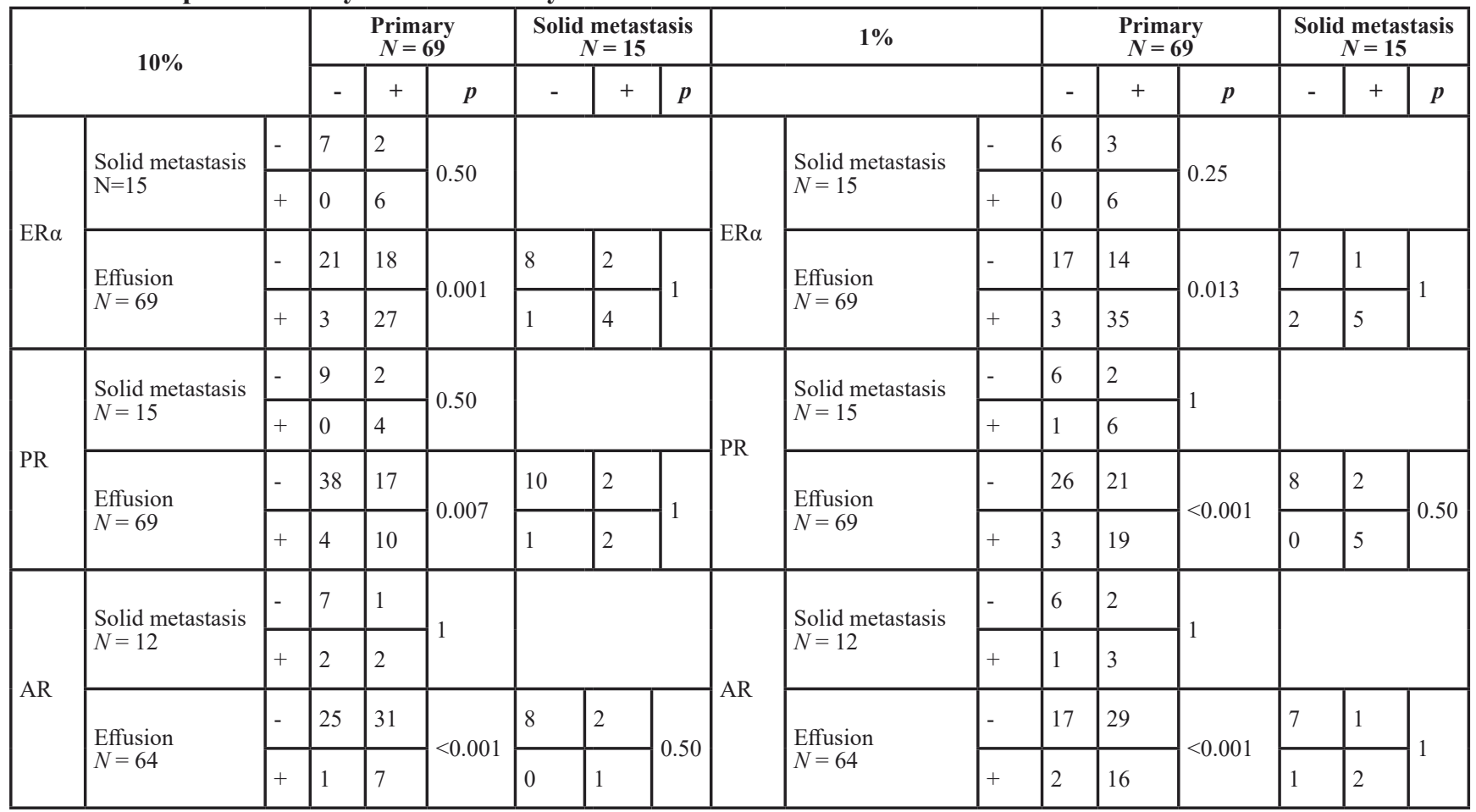

Data are shown for $10 \%$ and $1 \%$ cut-offs of positivity.

Table 3: HER2 receptor status of primary tumors and solid and effusion metastases of patients analyzed in this study.

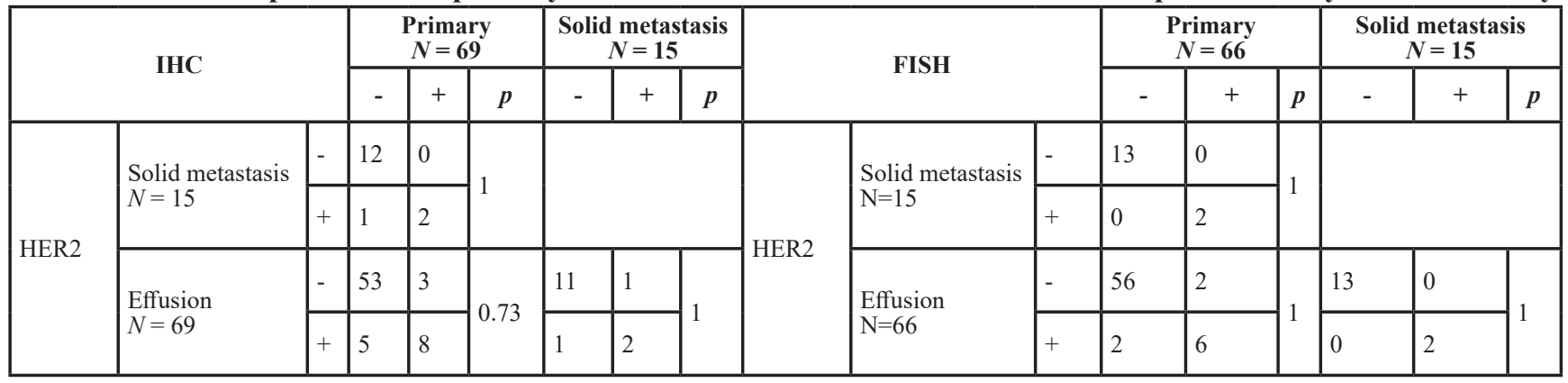

Data are shown for immunohistochemistry and FISH.

Out of 69 patients in our cohort, 27 patients had material available of more than one metastasis (multiple solid or effusion metastases; Supplementary table S1). Figure 2 depicts ER $\alpha$, PR and AR staining percentages and HER2 DAKO-scores for these patients. Large variation occurred during tumor progression from primary tumor to solid and effusion metastases, with no clear trend over time.

\section{Adjuvant endocrine therapy is associated with receptor conversion in pleural metastases}

Adjuvant endocrine therapy was given to $66 \%$ (33/50) of the patients (of whom treatment history was known), while 63\% (31/49) received adjuvant chemotherapy. For $45 \%(5 / 11)$ of HER2 amplified cases, trastuzumab was prescribed. In Supplementary Table S2 we provide the adjuvant therapy administration per receptor status for both the $1 \%$ and $10 \%$ thresholds for positivity.

Patients adjuvantly treated with endocrine therapy showed more often conversion of ER $\alpha$ ( $p=0.006$ or $\mathrm{p}$ $=0.058$ for the $10 \%$ or $1 \%$ thresholds for positivity, respectively) and AR ( $p=0.001$ or $p<0.001)$, but not of PR ( $p=0.060$ or $p=0.130$; Figure 3$)$. Adjuvant chemotherapy did not show such association (ER $\alpha$ : $p=$ 0.835 or $p=0.271$, PR: $p=0.383$ or $p=0.156$ and AR: $p=0.557$ or $p=0.927$ for the $10 \%$ or $1 \%$ thresholds for positivity, respectively).

For HER2, adjuvant trastuzumab treatment also influenced the change of receptor status $(p<0.001)$. Again, this effect was not seen for chemotherapy ( $p=$ 0.117 ). 


\section{Primary tumor}

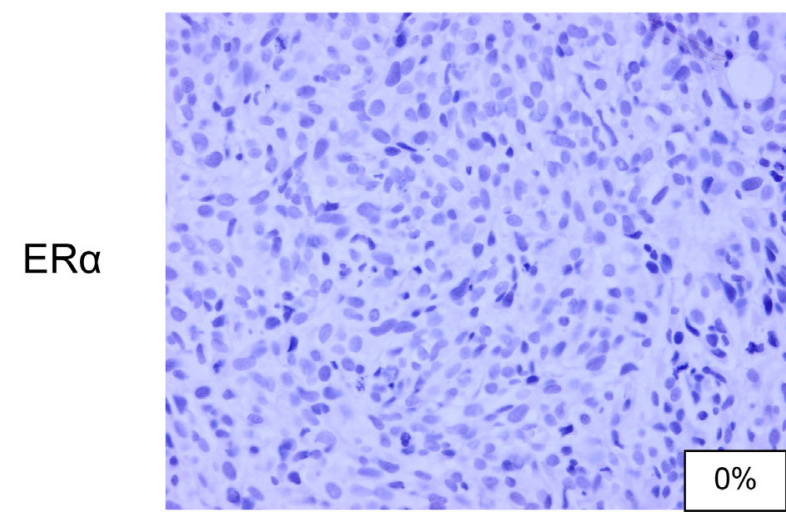

PR

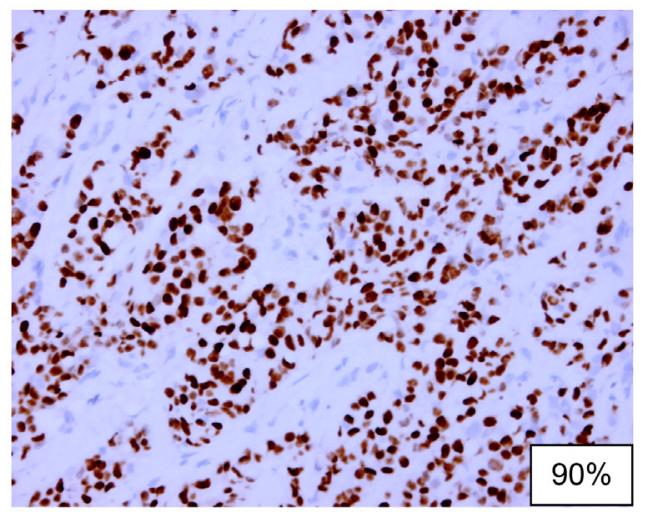

AR

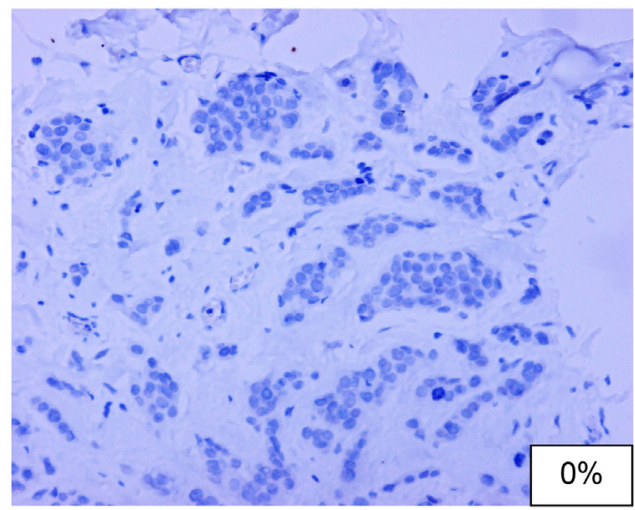

HER2
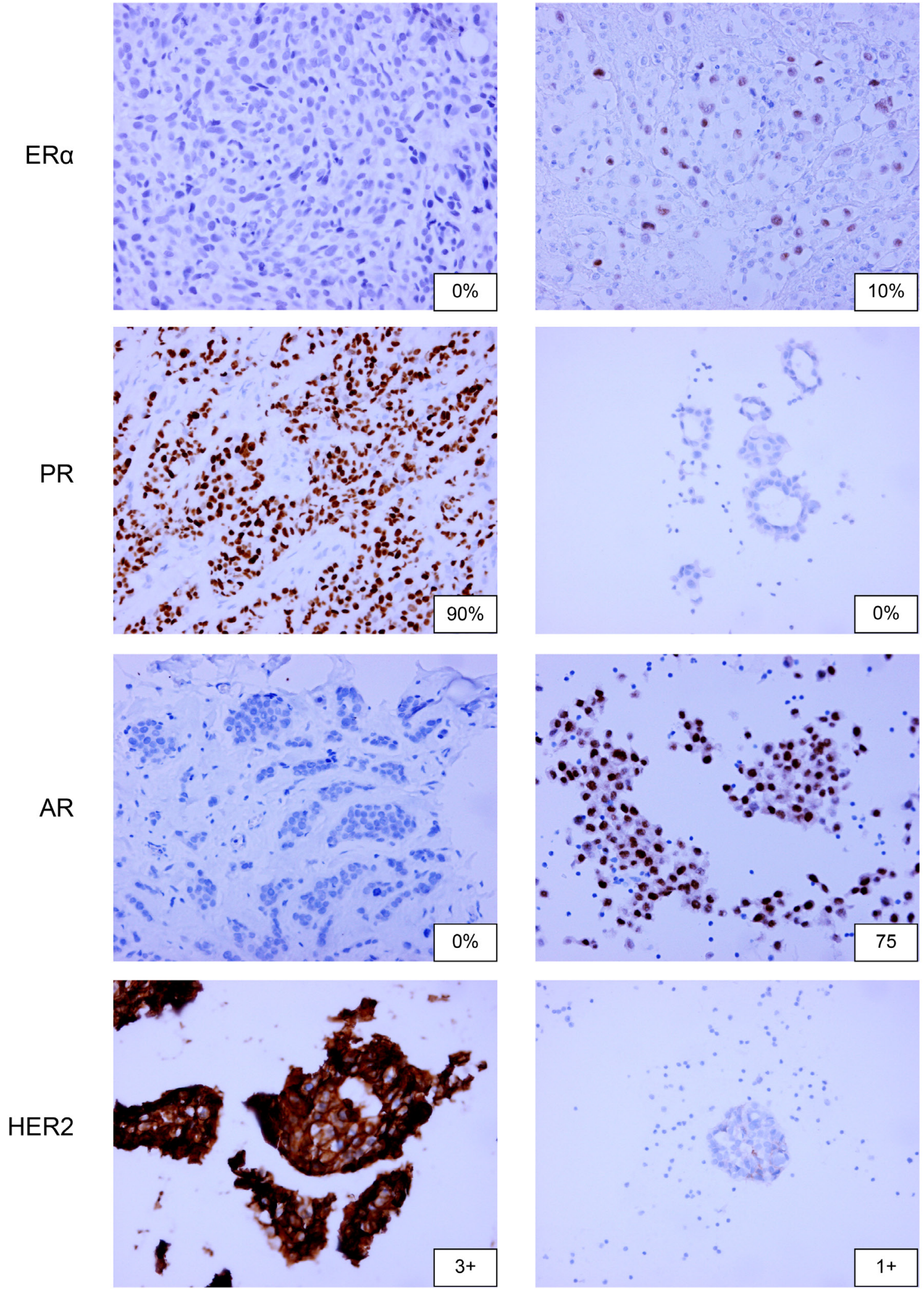

Figure 1: ERa, PR, AR and HER2 immunohistochemistry on paired primary breast tumors and pleural or peritoneal metastases. 20x magnification is used. 
Table 4: Differences in HER2 immunohistochemistry and FISH for $2+/ 3+$ or discordant cases.

\begin{tabular}{|l|c|c|c|c|c|}
\hline \multicolumn{2}{|c|}{ Primary tumor } & \multicolumn{2}{c|}{ Solid metastasis } & \multicolumn{2}{c|}{ Effusion metastasis } \\
\hline IHC & FISH & IHC & FISH & IHC & FISH \\
\hline $3+$ & amp & & & $3+$ & amp \\
\hline $3+$ & amp & & & $3+$ & amp \\
\hline $3+$ & amp & $3+$ & amp & $3+$ & amp \\
\hline $1+$ & no amp & & & $2+$ & amp \\
\hline 0 & & $1+$ & & $2+$ & no amp \\
\hline $3+$ & amp & & & $3+$ & no amp \\
\hline $3+$ & amp & $3+$ & amp & $2+$ & amp \\
\hline $3+$ & amp & & & $3+$ & amp \\
\hline $3+$ & amp & & & $3+$ & amp \\
\hline 0 & & $2+$ & no amp & 0 & \\
\hline $1+$ & no amp & & & $2+$ & no amp \\
\hline $2+$ & no amp & & & 0 & \\
\hline $3+$ & amp & & & $2+$ & no amp \\
\hline $3+$ & no amp & & & $3+$ & amp \\
\hline
\end{tabular}

\section{DISCUSSION}

Luminal breast cancer is hallmarked by expression and growth dependency on ER $\alpha$, which represents one of the cornerstones of adjuvant therapy in the treatment of breast cancer. Now that guidelines allow for the use of at least 5 years of endocrine therapeutics [24], and even 10 years for a subset of patients [25], it is not unlikely that such continuous and longitudinal ER $\alpha$-inhibition would directly invoke a strong evolutionary pressure on the tumor. For approximately $30 \%$ of patients, metastatic relapse of the tumor is observed [26], which also implies that the tumor cells managed to survive and proliferate despite multiple years of ER $\alpha$ inhibition. Since the efficacy of adjuvant endocrine therapy was only established during the end of the last century, leading to an increase in prescription [27], studies including samples before that time could not confirm the evolutionary pressure of these therapies.

Next to ER $\alpha$, also PR, AR and HER2 are treatment targets in the battle against breast cancer. For second or higher lines of therapy, megestrol acetate [28], bicalutamide [29] and trastuzumab [30] are only a few examples of drugs that have demonstrated their clinical utility in breast cancer treatment and continuous research is being performed to develop and optimize new therapies. Furthermore, PR and AR also have the potential to predict response to ER $\alpha$-targeted therapy; high PR expression in the presence [31] or even absence of ER $\alpha$ [32] is thought to predict an increased probability of benefit from anti-estrogen, while AR protein expression can induce tamoxifen resistance [33].

Receptor conversion in solid distant metastases is now a well-known phenomenon and may lead to suboptimal treatment, and most guidelines now recommend to biopsy distant metastases at presentation of metastatic disease [16, 34, 35]. Receptor status in malignant effusion specimens used to be determined only rarely, as in most cases characteristics of the primary tumor were deemed sufficient. However, in this study we demonstrated that receptor conversion in effusions is also a frequent phenomenon. Especially the high AR discordance we found is new and very relevant, since AR-targeted therapies are recently gaining interest for the treatment of ER $\alpha$-negative and endocrine therapy resistant breast cancer [36]. Even more interesting, in contrast to the high AR discordance in effusion metastases, relatively stable AR expression was described in solid metastases $[18,19]$, while ER $\alpha$, PR and HER2 conversion showed roughly the same pattern in effusion and solid metastases [12-14].

We show for the first time that receptor conversion for $E R \alpha$ and $A R$ in malignant effusions was more often seen in patients adjuvantly treated with endocrine therapy and for HER2 in patients treated with trastuzumab. For $\mathrm{ER} \alpha, \mathrm{PR}$ and HER 2 this was previously shown in primary breast cancer versus solid metastases [37-43]. Conversion occurred most often from positive to negative and could be explained by outgrowth of metastatic negative clones from the primary tumor under the selection pressure of prior therapies [44, 45]. However, ER $\alpha$-inhibitor induced AR conversion was not shown before and the mechanism of this finding remains elusive. Videlicet, tamoxifen and aromatase-inhibitors are not known to affect AR activity and are therefore not thought to inflict evident evolutionary selection pressure. Another explanation for conversion could be clonal dedifferentiation and selection of or evolution to more aggressive phenotypes [44, 46-48]. Also inadequate sampling of a heterogeneous tumor potentially leads to differences in receptor expression, which may 
explain some but clearly not all of the differences between primary breast cancer and metastases. Only one previous study reported ER $\alpha$ and PR receptor expression between primary breast tumors and 31 pleural effusion metastases, without mentioning treatment history. With expression rates of $59 \%$ and $51 \%$ for ER $\alpha$ and PR respectively and receptor conversion of $35 \%$ and $42 \%$, these findings corresponded to our results mostly in relation to ER $\alpha$ [49].

In patients with multiple effusion samples and solid metastases available, large variation in hormone and HER2 receptor expression occurred during tumor progression from primary tumor to solid and pleural metastases, with no clear trend over time. This could be explained by the different locations of metastases, since it was shown before that tumors with specific hormone receptor expression patterns show a distinct dissemination pattern [44]. Furthermore, most patients received multiple lines of therapy, potentially all imposing divergent evolutionary selection pressures on the metastatic cells. Also, in our cohort not all patients with ER $\alpha$ - and/or HER2-positive primary breast cancer received adjuvant endocrine or HER2-targeted therapy. This can be explained by the long sample inclusion period (1989-2016). Furthermore, we did not have access to treatment information of all included patients. Future studies addressing types, duration and number of therapies of all included patients would yield priceless information about the influence of systemic drugs on tumor progression.

Since generally less steroid receptor positivity was seen in peritoneal and pleural effusion metastases compared to their matched primary breast carcinomas, the question arises whether IHC staining on histologically processed cytology specimens is reliable. However, several studies have compared ER $\alpha, \mathrm{PR}$ and HER2 status in cell blocks to tissue blocks and found high concordance rates between cytology and histology specimens [50,
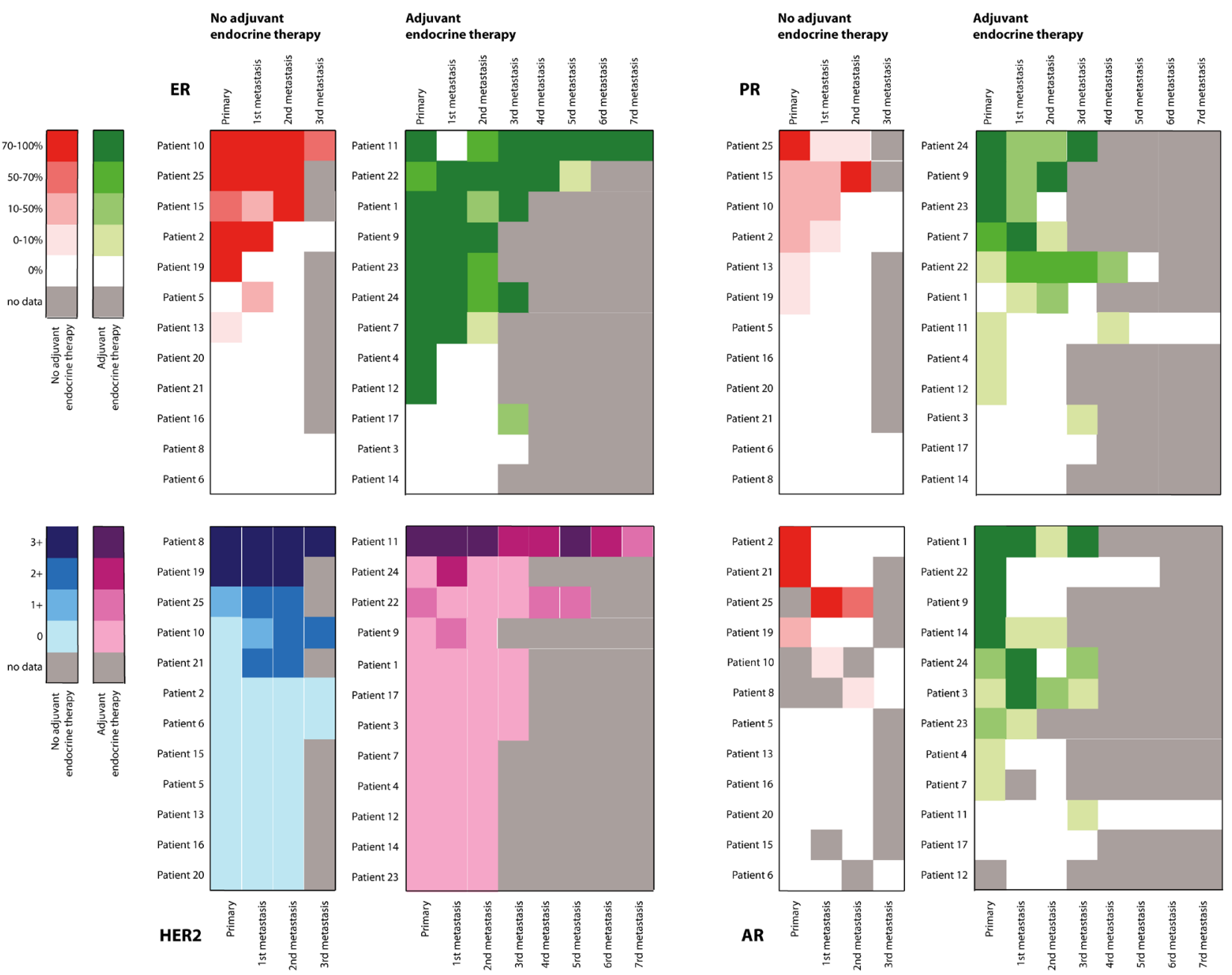

Figure 2: Heatmap of expression of ER $\alpha, P R, A R$ and HER2 in paired primary breast tumors and multiple pleural or peritoneal metastases per patient: progression over time. For ER $\alpha$, PR and AR, green represents patients adjuvantly treated with endocrine therapy; red represents patients not adjuvantly treated with endocrine therapy. For HER2, purple represents patients adjuvantly treated with endocrine therapy; blue represents patients not adjuvantly treated with endocrine therapy. 
51]. To prevent potential differences caused by such technical issues, we performed IHC staining on freshly cut cell block sections, used internal and external controls, assessed only the invasive (not the in situ) component and performed ISH on samples that scored $2+$ or $3+$ [52]. Since heterogeneous expression is not uncommon [53], we included only samples containing at least 20 tumor cells.

In summary, we have shown for the first time that $\mathrm{ER} \alpha, \mathrm{PR}, \mathrm{AR}$ and HER2 expression in primary breast cancers is frequently lost in peritoneal and pleural effusion metastases. For ER $\alpha$, PR and HER2 this is in line with previous findings in solid distant metastases, but AR conversion in late stages of tumor progression is a new observation. We demonstrate that this loss may be inflicted by the evolutionary selection pressure of adjuvant endocrine or targeted therapies, as such accounting for acquired therapy resistance. Considering Enzalutamide treatment, which blocks AR nuclear import, inhibits estrogen-driven MCF-7 cell proliferation (ref: https://breast-cancer-research.biomedcentral.com/ articles/10.1186/bcr3599), it is conceivable that ARloss would have a comparable effect on abrogating ER $\alpha$ function. Since more than $35 \%$ of hormone receptor positive primary tumors convert to $\mathrm{ER} \alpha$ and/or PR negative metastases or vice versa, determination of receptor status in malignant effusion specimens may help to optimize patient tailored hormonal treatment and is therefore recommended whenever possible. Especially the new finding of treatment-induced loss of AR protein expression as shown here, might have ramifications for clinical studies addressing AR-targeted therapies in metastatic breast cancer.

\section{MATERIALS AND METHODS}

\section{Material}

In total, 91 malignant effusion specimens derived from 69 female breast cancer patients were used for this study. Retrospectively, 71 cell blocks of pleural and peritoneal effusions from 56 patients were obtained from the departments of Pathology of the University Medical
A

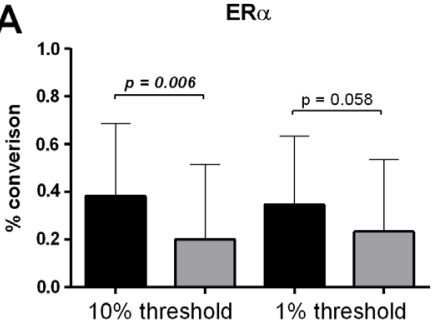

B

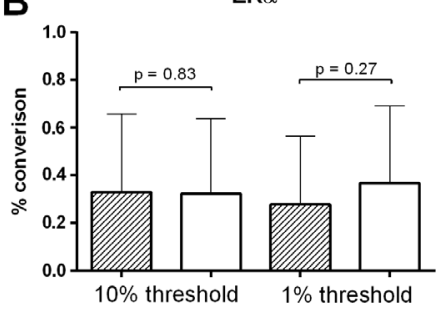

PR

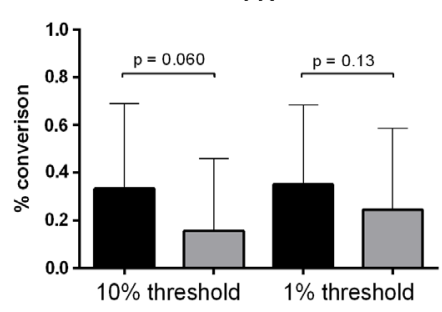

PR


C

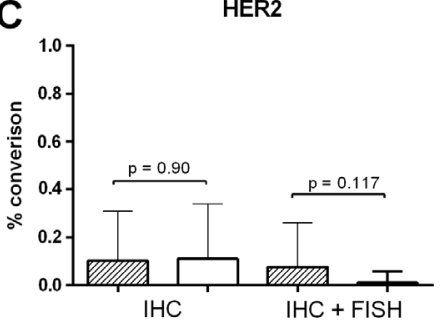

Adjuvant chemotherapy

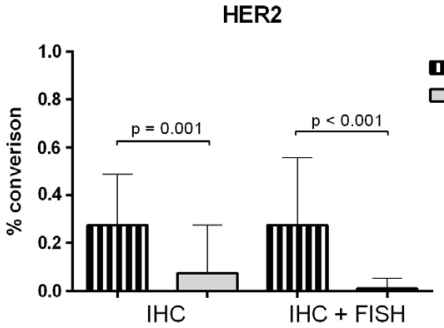

Figure 3: Conversion percentages for $\mathbf{E R} \alpha, \mathbf{P R}, \mathrm{AR}$ and HER2 compared to adjuvant therapy history. a. Conversion percentages for ER $\alpha$, PR and AR of patients that did and did not receive adjuvant endocrine therapy. Data for the $1 \%$ and $10 \%$ thresholds for positivity are shown. b. Conversion percentages for ER $\alpha$, PR and AR of patients that did and did not receive adjuvant chemotherapy. Data for the $1 \%$ and $10 \%$ thresholds for positivity are shown. c. Conversion percentages for HER2 of patients that did and did not receive adjuvant chemo- or trastuzumab therapy. Data for the for IHC only and IHC in combination with FISH are shown. 
Center Utrecht (39 patients), Rijnstate Hospital Arnhem (1 patient), Radboud University Medical Center Nijmegen (2 patients), Bronovo Hospital The Hague (1 patient), Meander Medical Center Amersfoort (2 patients), OLVG Amsterdam (1 patient), Pathology Laboratory Friesland (2 patients), Groene Hart Hospital Gouda (1 patient), Leiden University Medical Center (1 patient), St. Franciscus Hospital Rotterdam (5 patients), Isala Clinics Zwolle (1 patient), all in The Netherlands. Fourteen effusion samples from nine patients were collected prospectively in the Netherlands Cancer Institute in Amsterdam and six samples from four patients from the University Medical Center Utrecht. Selection criteria were: availability of tissue from both primary tumor and effusion metastases, more than 20 tumor cells per cell block, enough tissue to cut sections for IHC analyses on ER $\alpha, \mathrm{PR}, \mathrm{AR}, \mathrm{HER} 2$ and potentially FISH. Original diagnoses had been made between December 1989 and February 2016.

Cytology samples were initially fixed in isopropanolol and embedded in paraffin by Cellient, (Hologic). For each case, hematoxylin-eosin stained slides of the paraffin blocks were reviewed by a single experienced pathologist (PvD) to confirm the presence of malignancy in all cytology samples. Only samples containing at least 20 tumor cells were selected. BerEP4 monoclonal antibody staining (Monosan), labelling epithelial tissues without reacting with mesothelial cells, was used to confirm presence of tumor cells.

All samples were compared with the corresponding primary tumor and, when present, with one or more paired solid distant metastases (fifteen patients). All samples were recut and restained, using current standardized techniques (see below).

This study was performed in accordance with the medical ethical guidelines of the University Medical Center Utrecht. The use of anonymous or coded left over material for scientific purposes is part of the standard treatment agreement with patients and therefore ethical approval was not required [54].

\section{Immunohistochemistry}

IHC for ER $\alpha$, PR, HER2, AR and Ber-EP4 was carried out on full 4- $\mu \mathrm{m}$ sections with the Ventana (Ventana Medical Systems) according to the manufacturer's instructions with mouse monoclonal antibodies against Ber-EP4/Ep-CAM (1:800, BS14, Monosan) and AR (1:20, AR27, Novocastra) and rabbit monoclonal antibodies against ER $\alpha$ (ready-to-use, SP1, Roche), PR (ready-touse, 1E2, Roche) and HER2 (1:50, SP3, ThermoFisher). Appropriate controls were used throughout.

\section{Scoring}

Scoring of IHC slides was performed by consensus of two observers (PvD \& WS) in random order, blinded to other data. The adequacy of staining in the primary carcinoma was checked by also evaluating the normal breast parenchyma when present.

For ER $\alpha, \mathrm{PR}$ and AR, the percentage of positively stained nuclei was estimated side by side with the BEREp4 stained slide as a reference. Samples with $10 \%$ or more immunopositive malignant cells, regardless of staining intensity, were classified as ER $\alpha$ or PR positive (European standard). The same was done for the 1\% USA threshold.

HER2 expression was scored using the DAKO scoring system as $0,1+, 2+$ and $3+[55]$. HER2 expression was considered negative when 0 or $1+$, equivocal when $2+$ and positive when $3+$. We regarded HER 2 conversion as a shift from $0 / 1+/ 2+$ without amplification by FISH to $2+$ with amplification/3+ or vice versa.

\section{In situ hybridization}

All cases with $2+/ 3+$ and discordant results in primary tumors compared to paired metastases were subjected to fluorescence in situ hybridization using a HER2/CEP17 dual FISH probe (Cytocell) on 4- $\mu \mathrm{m}$ slides. Analysis was performed on a Leica DM5500 B microscope system with Application Suite Advanced Fluorescence Software (Leica Microsystems).

In short, formalin-fixed paraffin-embedded slides were deparaffinized and pretreated with citrate and protease buffers. Next, they were dehydrated and hybridized with $10 \mu \mathrm{l}$ probe in a ThermoBrite (Abbott Laboratories) at $37^{\circ} \mathrm{C}$ overnight. The next day, slides were washed in saline-sodium citrate buffers, counterstained with DAPI, dehydrated and mounted with Vectashield Mounting Medium (Vector Laboratories). One hundred tumor cell nuclei per tumor were assessed for HER2 gene and CEP17 probe signals at 100x magnification. The HER2/CEP17 ratio was calculated as well. A ratio below 1.8 was defined as a normal copy number, a ratio of 1.8-2.2 as an equivocal copy number and a ratio above 2.2 as gene amplification, according to the ASCO \& CAP guidelines [56].

\section{Statistics}

Expression frequency of ER $\alpha, \mathrm{PR}, \mathrm{AR}$ and HER2 was compared in the primary tumors versus paired effusion and solid metastases using Wilcoxon signed-rank test. Comparison of IHC expression in peritoneal and pleural effusions was performed using Mann-Whitney $\mathrm{U}$ test. Dichotomized conversion data (from positive to 
negative and vice versa) were calculated for $1 \%$ and $10 \%$ thresholds for positivity and compared by Mc Nemar's test. As steroid receptor conversion is clinically important if a patient converts from "ER $\alpha+$ or $\mathrm{PR}+$ " to $\mathrm{ER} \alpha-/ \mathrm{PR}-$, or from ER $\alpha-/ \mathrm{PR}$ - to "ER $\alpha+$ or $\mathrm{PR}+$ ", we calculated the frequency for these conversions as well. Statistical analysis was performed using IBM SPSS Statistics version 21 and visualized using GraphPad Prism 6.

\section{ACKNOWLEDGMENTS}

The Dutch Distant Breast Cancer Metastases Consortium included the Departments of Pathology from the University Medical Center Utrecht, Meander Medical Center Amersfoort, Hospital Gelderse Vallei Ede, Academic Medical Center Amsterdam, Medical Center Alkmaar, Radboud University Nijmegen Medical Center, Canisius Wilhelmina Hospital Nijmegen, VU University Medical Center Amsterdam, The Netherlands Cancer Institute Amsterdam, Groene Hart Hospital Gouda, University Medical Center Groningen, St Antonius Hospital Nieuwegein, Diakonessenhuis Utrecht, Isala klinieken Zwolle, Erasmus Medical Center Rotterdam, Gelre Hospital Apeldoorn and the Laboratories for Pathology Dordrecht, 's Hertogenbosch, Terneuzen, Symbiant Zaandam, Sazinon, Hoogeveen, Oost Nederland Enschede (LabPON), all in The Netherlands. for cases.

We thank Stichting PALGA for the national query

\section{CONFLICTS OF INTEREST}

This manuscript has neither been published, nor is currently under revision elsewhere and none of the authors has a conflict of interest.

\section{FUNDING}

Supported by Dutch Cancer Society grant UU 20115195 and Philips Consumer Lifestyle. Wilbert Zwart is supported by a Dutch Cancer Society KWF/ Alpe d'HuZes Bas Mulder Award and a Netherlands Organization for Scientific Research NWO VIDI grant. No benefits in any form have been or will be received from a commercial party related directly or indirectly to the subject of this manuscript. No portion of the contents of this manuscript has been published previously.

\section{REFERENCES}

1. Ferlay J, Soerjomataram I, Dikshit R, Eser S, Mathers C, Rebelo M, Parkin DM, Forman D, Bray F. Cancer incidence and mortality worldwide: sources, methods and major patterns in GLOBOCAN 2012. International journal of cancer. 2015; 136: E359-86.
2. Fentiman IS, Millis R, Sexton S, Hayward JL. Pleural effusion in breast cancer: a review of 105 cases. Cancer. 1981; 47: 2087-2092.

3. Raju RN, Kardinal CG. Pleural effusion in breast carcinoma: analysis of 122 cases. Cancer. 1981; 48: 25242527.

4. Wilkes JD, Fidias P, Vaickus L, Perez RP. Malignancyrelated pericardial effusion. 127 cases from the Roswell Park Cancer Institute. Cancer. 1995; 76: 1377-1387.

5. Buck M, Ingle JN, Giuliani ER, Gordon JR, Therneau TM. Pericardial effusion in women with breast cancer. Cancer. 1987; 60: 263-269.

6. Zamboni MM, da Silva CT Jr, Baretta R, Cunha ET, Cardoso GP. Important prognostic factors for survival in patients with malignant pleural effusion. BMC pulmonary medicine. 2015; 15: 29.

7. Singer TS, Sulkes A, Biran S. Pleural effusion in breast cancer: influence upon clinical course and survival. Chemioterapia. 1986; 5: 66-69.

8. Bielsa S, Salud A, Martinez M, Esquerda A, Martin A, Rodriguez-Panadero F, Porcel JM. Prognostic significance of pleural fluid data in patients with malignant effusion. European journal of internal medicine. 2008; 19: 334-339.

9. Di Lorenzo D, Zaniboni A, Simoncini E, Marpicati P, Montini E, Alghisi A, Gorni F, Marini G. Estrogen and progesterone receptors in neoplastic cells of metastatic pleural effusion of breast carcinoma before and after tamoxifen therapy. Correlation with the clinical response. Chemioterapia. 1986; 5: 232-236.

10. Shinohara T, Yamada H, Fujimori Y, Yamagishi K. Malignant pleural effusion in breast cancer 12 years after mastectomy that was successfully treated with endocrine therapy. The American journal of case reports. 2013; 14: 184-187.

11. Watanabe $\mathrm{T}, \mathrm{Wu} \mathrm{JZ}$, Morikawa $\mathrm{K}$, Fuchigami M, Kuranami M, Adachi I, Yamaguchi K, Abe K. In vitro sensitivity test of breast cancer cells to hormonal agents in a radionucleotide-incorporation assay. Japanese journal of cancer research. 1990; 81: 536-543.

12. Hoefnagel LD, van de Vijver MJ, van Slooten HJ, Wesseling P, Wesseling J, Westenend PJ, Bart J, Seldenrijk CA, Nagtegaal ID, Oudejans J, van der Valk P, van der Groep P, de Vries EG, et al. Receptor conversion in distant breast cancer metastases. Breast cancer research. 2010; 12: R75.

13. Hoefnagel LD, Moelans CB, Meijer SL, van Slooten HJ, Wesseling P, Wesseling J, Westenend PJ, Bart J, Seldenrijk CA, Nagtegaal ID, Oudejans J, van der Valk P, van Gils $\mathrm{CH}$, et al. Prognostic value of estrogen receptor alpha and progesterone receptor conversion in distant breast cancer metastases. Cancer. 2012; 118: 4929-4935.

14. Hoefnagel LD, van der Groep P, van de Vijver MJ, Boers JE, Wesseling P, Wesseling J, Dutch Distant Breast Cancer Metastases Consortium, van der Wall E, van Diest PJ. 
Discordance in ERalpha, PR and HER2 receptor status across different distant breast cancer metastases within the same patient. Annals of Oncology. 2013; 24: 3017-3023.

15. Hammond ME, Hayes DF, Wolff AC, Mangu PB, Temin S. American society of clinical oncology/college of american pathologists guideline recommendations for immunohistochemical testing of estrogen and progesterone receptors in breast cancer. Journal of oncology practice / American Society of Clinical Oncology. 2010; 6: 195-197.

16. Carlson RW, Allred DC, Anderson BO, Burstein HJ, Edge SB, Farrar WB, Forero A, Giordano SH, Goldstein LJ, Gradishar WJ, Hayes DF, Hudis CA, Isakoff SJ, et al. Metastatic breast cancer, version 1.2012: featured updates to the NCCN guidelines. Journal of the National Comprehensive Cancer Network. 2012; 10: 821-829.

17. Pietri E, Conteduca V, Andreis D, Massa I, Melegari E, Sarti S, Cecconetto L, Schirone A, Bravaccini S, Serra P, Fedeli A, Maltoni R, Amadori D, et al. Androgen receptor signaling pathways as a target for breast cancer treatment. Endocrine-related cancer. 2016.

18. D'Amato NC, Gordon MA, Babbs B, Spoelstra NS, Carson Butterfield KT, Torkko KC, Phan VT, Barton VN, Rogers TJ, Sartorius CA, Elias A, Gertz J, Jacobsen BM, et al. Cooperative Dynamics of AR and ER Activity in Breast Cancer. Molecular cancer research. 2016.

19. Grogg A, Trippel M, Pfaltz K, Ladrach C, Droeser RA, Cihoric N, Salhia B, Zweifel M, Tapia C. Androgen receptor status is highly conserved during tumor progression of breast cancer. BMC cancer. 2015; 15: 872.

20. Bertozzi S, Londero AP, Cedolini C, Uzzau A, Seriau L, Bernardi S, Bacchetti S, Pasqual EM, Risaliti A. Prevalence, risk factors, and prognosis of peritoneal metastasis from breast cancer. SpringerPlus. 2015; 4: 688.

21. Apffelstaedt JP, Van Zyl JA, Muller AG. Breast cancer complicated by pleural effusion: patient characteristics and results of surgical management. Journal of surgical oncology. 1995; 58: 173-175.

22. Nakayama Y, Nakagomi H, Omori M, Inoue M, Takahashi K, Maruyama M, Takano A, Furuya K, Amemiya K, Ishii E, Oyama T. Benefits of using the cell block method to determine the discordance of the HR/HER2 expression in patients with metastatic breast cancer. Breast cancer (Tokyo, Japan). 2016; 23: 633-639.

23. Arihiro K, Oda M, Ogawa K, Tominaga K, Kaneko Y, Shimizu T, Matsumoto S, Oda M, Kurita Y, Taira Y. Discordant HER2 status between primary breast carcinoma and recurrent/metastatic tumors using fluorescence in situ hybridization on cytological samples. Japanese journal of clinical oncology. 2013; 43: 55-62.

24. Fisher B, Dignam J, Bryant J, Wolmark N. Five versus more than five years of tamoxifen for lymph node-negative breast cancer: updated findings from the National Surgical Adjuvant Breast and Bowel Project B-14 randomized trial. Journal of the National Cancer Institute. 2001; 93: 684-690.
25. Goss PE, Ingle JN, Pritchard KI, Robert NJ, Muss H, Gralow J, Gelmon K, Whelan T, Strasser-Weippl K, Rubin S, Sturtz K, Wolff AC, Winer E, et al. Extending Aromatase-Inhibitor Adjuvant Therapy to 10 Years. The New England journal of medicine. 2016; 375: 209-219.

26. O'Shaughnessy J. Extending survival with chemotherapy in metastatic breast cancer. The oncologist. 2005; 10 Suppl 3: 20-29.

27. Johnson TP, Ford L, Warnecke RB, Nayfield SG, Kaluzny A, Cutter G, Gillings D, Sondik E, Ozer H. Effect of a National Cancer Institute Clinical Alert on breast cancer practice patterns. Journal of clinical oncology. 1994; 12: 1783-1788.

28. Bines J, Dienstmann R, Obadia RM, Branco LG, Quintella DC, Castro TM, Camacho PG, Soares FA, Costa ME. Activity of megestrol acetate in postmenopausal women with advanced breast cancer after nonsteroidal aromatase inhibitor failure: a phase II trial. Annals of Oncology. 2014; 25: 831-836.

29. Arce-Salinas C, Riesco-Martinez MC, Hanna W, Bedard P, Warner E. Complete Response of Metastatic Androgen Receptor-Positive Breast Cancer to Bicalutamide: Case Report and Review of the Literature. Journal of clinical oncology. 2016; 34: e21-4.

30. Hortobagyi GN. Trastuzumab in the treatment of breast cancer. The New England journal of medicine. 2005; 353: 1734-1736.

31. Luoh SW, Ramsey B, Park B, Keenan E. Quantitative progesterone receptor expression and efficacy of antiestrogen therapy in breast cancer. The breast journal. 2014; 20: 46-52.

32. Shen T, Brandwein-Gensler M, Hameed O, Siegal GP, Wei S. Characterization of estrogen receptor-negative/ progesterone receptor-positive breast cancer. Human pathology. 2015; 46: 1776-1784.

33. De Amicis F, Thirugnansampanthan J, Cui Y, Selever J, Beyer A, Parra I, Weigel NL, Herynk MH, Tsimelzon A, Lewis MT, Chamness GC, Hilsenbeck SG, Ando S, et al. Androgen receptor overexpression induces tamoxifen resistance in human breast cancer cells. Breast cancer research and treatment. 2010; 121: 1-11.

34. Van Poznak C, Somerfield MR, Bast RC, Cristofanilli M, Goetz MP, Gonzalez-Angulo AM, Hicks DG, Hill EG, Liu MC, Lucas W, Mayer IA, Mennel RG, Symmans WF, et al. Use of Biomarkers to Guide Decisions on Systemic Therapy for Women With Metastatic Breast Cancer: American Society of Clinical Oncology Clinical Practice Guideline. Journal of clinical oncology. 2015; 33: 2695-2704.

35. Cardoso F, Costa A, Norton L, Cameron D, Cufer T, Fallowfield L, Francis P, Gligorov J, Kyriakides S, Lin N, Pagani O, Senkus E, Thomssen C, et al. 1st International consensus guidelines for advanced breast cancer (ABC 1). Breast (Edinburgh, Scotland). 2012; 21: 242-252.

36. Garay JP, Park BH. Androgen receptor as a targeted therapy 
for breast cancer. American journal of cancer research. 2012; 2: 434-445.

37. Curtit E, Nerich V, Mansi L, Chaigneau L, Cals L, Villanueva C, Bazan F, Montcuquet P, Meneveau N, Perrin S, Algros MP, Pivot X. Discordances in estrogen receptor status, progesterone receptor status, and HER2 status between primary breast cancer and metastasis. The oncologist. 2013; 18: 667-674.

38. Duchnowska R, Dziadziuszko R, Trojanowski T, Mandat T, Och W, Czartoryska-Arlukowicz B, Radecka B, Olszewski W, Szubstarski F, Kozlowski W, Jarosz B, Rogowski W, Kowalczyk A, et al. Conversion of epidermal growth factor receptor 2 and hormone receptor expression in breast cancer metastases to the brain. Breast cancer research . 2012; 14: R119.

39. Idirisinghe PK, Thike AA, Cheok PY, Tse GM, Lui PC, Fook-Chong S, Wong NS, Tan PH. Hormone receptor and c-ERBB2 status in distant metastatic and locally recurrent breast cancer. Pathologic correlations and clinical significance. American Journal of Clinical Pathology. 2010; 133: 416-429.

40. Jensen JD, Knoop A, Ewertz M, Laenkholm AV. ER, HER2, and TOP2A expression in primary tumor, synchronous axillary nodes, and asynchronous metastases in breast cancer. Breast cancer research and treatment. 2012; 132: 511-521.

41. Nakamura R, Yamamoto N, Onai Y, Watanabe Y, Kawana H, Miyazaki M. Importance of confirming HER2 overexpression of recurrence lesion in breast cancer patients. Breast cancer (Tokyo, Japan). 2013; 20: 336-341.

42. Yonemori K, Tsuta K, Shimizu C, Hatanaka Y, Hashizume K, Ono M, Nakanishi Y, Hasegawa T, Miyakita Y, Narita Y, Shibui S, Fujiwara Y. Immunohistochemical profiles of brain metastases from breast cancer. Journal of neurooncology. 2008; 90: 223-228.

43. Bogina G, Bortesi L, Marconi M, Venturini M, Lunardi G, Coati F, Massocco A, Manfrin E, Pegoraro C, Zamboni G. Comparison of hormonal receptor and HER-2 status between breast primary tumours and relapsing tumours: clinical implications of progesterone receptor loss. Virchows Archiv. 2011; 459: 1-10.

44. Kuukasjarvi T, Karhu R, Tanner M, Kahkonen M, Schaffer A, Nupponen N, Pennanen S, Kallioniemi A, Kallioniemi OP, Isola J. Genetic heterogeneity and clonal evolution underlying development of asynchronous metastasis in human breast cancer. Cancer research. 1997; 57: 15971604.

45. Rasbridge SA, Gillett CE, Seymour AM, Patel K, Richards MA, Rubens RD, Millis RR. The effects of chemotherapy on morphology, cellular proliferation, apoptosis and oncoprotein expression in primary breast carcinoma. British journal of cancer. 1994; 70: 335-341.

46. Sari E, Guler G, Hayran M, Gullu I, Altundag K, Ozisik Y. Comparative study of the immunohistochemical detection of hormone receptor status and HER-2 expression in primary and paired recurrent/metastatic lesions of patients with breast cancer. Medical oncology (Northwood, London, England). 2011; 28: 57-63.

47. Amir E, Miller N, Geddie W, Freedman O, Kassam F, Simmons C, Oldfield M, Dranitsaris G, Tomlinson G, Laupacis A, Tannock IF, Clemons M. Prospective study evaluating the impact of tissue confirmation of metastatic disease in patients with breast cancer. Journal of clinical oncology. 2012; 30: 587-592.

48. Edgerton SM, Moore D 2nd, Merkel D, Thor AD. erbB2 (HER-2) and breast cancer progression. Applied Immunohistochemistry \& Molecular Morphology. 2003; 11: 214-221.

49. Schwarz C, Lubbert H, Rahn W, Schonfeld N, Serke M, Loddenkemper R. Medical thoracoscopy: hormone receptor content in pleural metastases due to breast cancer. The European respiratory journal. 2004; 24: 728-730.

50. Moriki T, Takahashi T, Ueta S, Mitani M, Ichien M. Hormone receptor status and HER2/neu overexpression determined by automated immunostainer on routinely fixed cytologic specimens from breast carcinoma: correlation with histologic sections determinations and diagnostic pitfalls. Diagnostic cytopathology. 2004; 30: 251-256.

51. Shabaik A, Lin G, Peterson M, Hasteh F, Tipps A, Datnow B, Weidner N. Reliability of Her2/neu, estrogen receptor, and progesterone receptor testing by immunohistochemistry on cell block of FNA and serous effusions from patients with primary and metastatic breast carcinoma. Diagnostic cytopathology. 2011; 39: 328-332.

52. Fetsch PA, Abati A. The effects of antibody clone and pretreatment method on the results of HER2 immunostaining in cytologic samples of metastatic breast cancer: A query and a review of the literature. Diagnostic cytopathology. 2007; 35: 319-328.

53. Cormier JN, Hijazi YM, Abati A, Fetsch P, Bettinotti M, Steinberg SM, Rosenberg SA, Marincola FM. Heterogeneous expression of melanoma-associated antigens and HLA-A2 in metastatic melanoma in vivo. International journal of cancer. 1998; 75: 517-524.

54. van Diest PJ. No consent should be needed for using leftover body material for scientific purposes. BMJ (Clinical research ed.). 2002; 325: 648-651.

55. Hammond ME. ASCO-CAP guidelines for breast predictive factor testing: an update. Applied Immunohistochemistry \& Molecular Morphology. 2011; 19: 499-500.

56. Wolff AC, Hammond ME, Hicks DG, Dowsett M, McShane LM, Allison KH, Allred DC, Bartlett JM, Bilous M, Fitzgibbons P, Hanna W, Jenkins RB, Mangu PB, et al. Recommendations for human epidermal growth factor receptor 2 testing in breast cancer: American Society of Clinical Oncology/College of American Pathologists clinical practice guideline update. Journal of clinical oncology. 2013; 31: 3997-4013. 